\title{
The international technological nuclear cooperation landscape: A new dataset and network analysis
}

\author{
Jessica Jewell ${ }^{\mathrm{a}, \mathrm{b}}$, Marta Vetier ${ }^{\mathrm{c}}$, and Daniel Garcia Cabrera ${ }^{\mathrm{a}}$ \\ a International Institute for Applied Systems Analysis, Schlossplatz 1, A-2361 Laxenburg, Austria \\ b Centre for Energy and Climate Transformations and Geography Department, University of Bergen, \\ Fosswinckelsgate 6, PB 7802, N-5020 Bergen, Norway \\ c Department of Environmental Science and Policy, Central European University, Nádor utca 9, 1051 Budapest, \\ Hungary
}

\section{Abstract}

The pursuit of civil nuclear power, frequently justified in the name of national energy security, paradoxically entangles most states in long-term interdependencies with the few countries capable of supplying nuclear technologies. These interdependencies are insufficiently documented and poorly understood. This article presents and analyzes a new dataset of nuclear cooperation agreements signed or announced between 2000 and 2015. We find that Russia and the US dominate international technological nuclear cooperation, with the US' dominance particularly prominent in safety and security and Russia's - in nuclear power plant construction, reactor and fuel supply, decommissioning and waste. When it comes to these technologies, Russia is the supplier in approximately half of all agreements; France, the US, China, Korea, and Japan together account for another $40 \%$. All in all, six countries are suppliers in over $90 \%$ of all international nuclear agreements, a far higher supplier concentration than in oil and gas markets. These results show that the global future of nuclear power depends as much on international cooperation as on national motivations and capacities. Effective policies and institutions supporting the safe use of nuclear power should therefore be directed at managing its international as well as national aspects. 


\section{Introduction}

In the run-up to the Paris climate talks, Jim Hansen and three other prominent climate scientists argued that nuclear power "will make the difference between the world missing crucial climate targets or achieving them" (Hansen et al., 2015). The argument sparked a vigorous debate on whether nuclear power expansion is even feasible, particularly given its history of rising costs and roots in vertically-integrated electricity markets (Bradford, 2015; Oreskes, 2015). This debate framed nuclear energy as primarily a national project. Hansen and colleagues argued that nuclear expansion "is technically achievable because France and Sweden were able to ramp up nuclear power to high levels in just 15-20 years". Oreskes countered, arguing expansion is unlikely given that France cannot even build a nuclear power plant on-time and under-budget.

Historically, the expansion of nuclear energy in frontrunner countries was a national effort: in the 1950s and 60s the Soviets, British, Americans and Canadians all started and expanded their nuclear programs based on domestic technologies. Even in countries where the introduction of nuclear power relied on foreign involvement, the programs were relatively quickly 'localized' and by the 1980s looked by and large national. Such experiences are well-documented in France (Hecht, 2001), West Germany (Mez and Piening, 2002), Japan (Smith and Rose, 1989), and Korea (Choi et al., 2009). ${ }^{1}$ Yet, the techno-national view of nuclear power may be less relevant in the future, when its biggest expansion is expected in developing and emerging economies (IAEA, 2014a) that have historically relied on technology transfer from nuclear frontrunners (Poneman, 1982). In an analysis of some 50 countries with aspirations to start a nuclear power program, Jewell (2011) concluded that very few of them will be able to do so without strong international support.

\footnotetext{
1 The Chinese actually designed and built their first nuclear power plant but since then have imported technology from France, Canada, Russia and the US (Zeng et al., 2016).
} 
There are cases where insufficient international support undermined the success of national nuclear power programs. In Turkey, disagreements between vendor countries and the government led to the failure of two of the country's attempts to introduce nuclear power (Jewell and Ates, 2015). The country is currently relying on two intergovernmental agreements in its fifth attempt: one with Russia and one with a Franco-Japanese consortium. The Russian agreement is a buildown-operate arrangement under which Russia will build the nuclear power plant as well as supply it with fuel, personnel and waste management in exchange for ownership and a guaranteed electricity price for a set period of time. A similar agreement with Russia is being implemented in Belarus and also under consideration in Hungary (WNN, 2016). These types of deals have raised concerns within national security communities in the West especially when the client is a NorthAtlantic Treaty Organization (NATO) member (Galluci and Schellenberger, 2017). Russia's dominance in the reactor-supply market is attracting attention from international relations and security communities (Galluci and Schellenberger, 2017; Saha, 2017). However, Russia is not the only active supplier today. A South Korean company is building a new nuclear power plant in the United Arab Emirates (UAE). Thus, the debate on the future of nuclear power should not be analyzed only in terms of national capacities and motivation to build and operate nuclear power plants but also in terms of the potential for and constraints to international cooperation.

In spite of the importance of international cooperation in the development of nuclear power, the literature on the topic is fragmented. There is a long tradition of scholarly work investigating the proliferation risk from spreading nuclear know-how (e.g. Fuhrmann, 2009a; 2009b; Kroenig, 2009a; 2009b; Warburg, 2012) including the proliferation risks of a future nuclear power expansion (Ebinger and Massy, 2010; Lehtveer and Hedenus, 2015a). However, the empirical research on the current global nuclear energy landscape does not systematically answer which countries may play a major role shaping the future of nuclear energy. There are a few recent single cases and industry reports (Galluci and Schellenberger, 2017; Ramberg, 2015; Saha, 2017; WNA, 2016a) and broad 
overviews of fuel fabrication (IAEA 2012), nuclear power plant supply (Cherp et al. 2012) and technology supply chain capacities (Brutschin and Jewell 2018). Additionally, work on nuclear clients, distinguishes between nuclear independents, who develop nuclear power on their own and dependents, who prefer rapid and cheap deployment by importing the technology (Poneman 1982). More recently, Lantis (2014) is one of the first scholars to look at the interplay between suppliers and clients by studying the negotiation processes and the role of strategic and economic considerations in international nuclear cooperation between three suppliers (the United States, Japan and Russia) in two developing markets (Jordan and Vietnam).

The main insights that emerge from this literature are that: (1) there are significant asymmetries within the nuclear technology market and (2) the geography and international political economy of international cooperation in nuclear energy differs between different parts of the nuclear supply chain (Brutschin and Jewell, 2018). However, this literature does not answer the question: Which types of arrangements, countries and practices will shape the future of nuclear energy?

In this article, we explore this question through a systematic analysis of nuclear cooperation and break this overarching research question into three sub-questions:

1. What are the main types of international nuclear energy cooperation and how widespread is each type of cooperation?

2. Which countries are the main actors in each type of international technological nuclear energy cooperation?

3. What are the characteristics of the international technological nuclear energy cooperation network?

We define nuclear cooperation as when two or more states share information, knowledge or material resources related to nuclear power technologies. We answer the first research question by separating different parts of the nuclear supply chain and considering separately technological 
cooperation and uranium mining and supply. With respect to the former, we further differentiate supportive cooperation and capacity building and exchange of knowledge (not involving concrete infrastructure development or material handling) from concrete cooperation. We also differentiate between cooperation involving asymmetric supplier-client relationships and more symmetric partnerships. We analyze these different types of cooperation by descriptive statistics.

For the second and third research questions, we focus only on international technological nuclear cooperation and exclude uranium-related agreements. We do this for two reasons. First, a state's pursuit of and expansion of nuclear power is dependent on first and foremost acquiring the technology and not on uranium imports; the leading exporters of nuclear technologies are not the leading exporters of uranium (Brutschin and Jewell, 2018). Second, our method relies on international cooperation as a proxy for dominance in the international nuclear landscape. For uranium, a much better measure would be uranium trade (such as UN Comtrade (2016)) which is beyond the scope of this article. We answer the second and third research questions with a combination of descriptive statistics and network analysis. The former is a toolset which has been used to examine the structure of relationships between countries (Hafner-Burton et al., 2009; Lloyd et al., 2009; Maoz, 2012; Nordlund, 2011) and how these relationships determine, constrain and enable their activities (MaOz, 2011). The details of our methodology are described in the next section followed by a report of our results related to each of the research questions and a discussion of the limitations of our approach and our conclusions.

\section{Methods}

\subsection{Data collection}

We define international nuclear cooperation as activities in which two or more states share, exchange, or combine material resources, knowledge, or information related to the development 
of nuclear power technologies. To study such cooperation, we built an original dataset of nuclear energy cooperation agreements and non-binding statements of cooperation (memoranda of understanding - MoUs - and policy statements) involving two or more countries and concluded between 2000-2015. In this article, we call these documents "cooperation units". Using cooperation agreements is increasingly being used to study interactions between states in several disciplines including international relations (Kinne 2013, Dorussen et al 2016, Gallop 2016), environmental governance (Hollway et al 2016, Bodin and Prell 2011) and economics (Currarini et al 2015, Serrano 2003, Saban et al 2010). In this piece, we analyze technological interactions between states in order to understand how it may shape future energy choices. We focus on post2000 accounts of international nuclear cooperation because it captures cooperation efforts which are actively shaping today's nuclear power programs. In addition to cases where there was evidence that a cooperation agreement was signed between two or more countries, we included data on non-binding statements of cooperation related to cooperation. The dataset was compiled between June 2014 and February 2015 from open sources and supplemented with a previously-published catalogue of nuclear cooperation agreements from Keeley (2009a; 2009b). Our dataset includes the following information for each agreement: title of the cooperation unit, supplier, client and partner countries, number of parties, type of cooperation, and reference.

We compiled the dataset from five sources: the World Nuclear Association website's Country Profiles (WNA, n.d.), news articles from the Nuclear Security Science and Policy Institute (NSSPI, n.d.), the World Nuclear News database (WNN, n.d.), a catalogue of bi-national cooperation maintained by James F. Keeley (2009b; 2009a) and targeted online searches. Our method of data collection followed five steps. First, we read the WNA profile for the 50 countries which are listed to identify cooperation units. Second, we searched WNN and the NSSPI databases for news articles covering agreements of nuclear cooperation and/or statements of cooperation related to nuclear energy. Once a cooperation agreement between two countries was identified (including 
those countries not on the $W N A$ list), we searched for it in Google using the following formula: "nuclear agreement" + "country X" + "country Y". Any information we found was listed in the database with a reference to the most complete (preferably primary) data source. Third, we integrated Keeley's catalogue of bi-national nuclear cooperation agreements for the relevant time period. ${ }^{2}$ Finally, to complement the information from existing sources, we used Google to search for "nuclear agreement" and "country X" as well as "nuclear cooperation" and "country X" for all countries which had at least one cooperation agreement in either of the existing databases, have nuclear power, or are actively developing nuclear power. ${ }^{3}$

\subsection{Coding cooperation units}

We began coding each cooperation unit by recording whether it was a formally signed agreement or a non-binding agreement (joint political announcement or memorandum of understanding). In the next step, we coded each cooperation unit according to the type of cooperation it included. Similar to Brutschin and Jewell (2018), we consider international technological nuclear cooperation in two distinct sectors: (1) nuclear power plant construction, reactor manufacturing, and nuclear fuel cycle; and (2) uranium mining and supply. We call cooperation related to nuclear reactor construction and manufacturing and the nuclear fuel cycle, technological cooperation and related to uranium mining and trade, uranium cooperation - Table 1. Within technological cooperation we further distinguish concrete cooperation related to the nuclear power plant construction and operation, reactor supply, the nuclear fuel cycle and decommissioning and waste

\footnotetext{
${ }^{2}$ In combining these two databases, we cross-checked the agreements in order to eliminate all repetitions.

3 The references we used to identify each of those cases includes: the Power Reactor Information System from the IAEA (IAEA, 2010), country profiles from the World Nuclear Association (WNA, n.d.), and recent reviews on the nuclear energy industry (Rogner, 2013; Schneider and Froggatt, 2013).
} 
management ${ }^{4}$ and supportive cooperation related to knowledge transfer, training, nuclear safety and security, and planning, regulation and supportive infrastructure - Table 1 .

We coded cooperation categories and sub-categories in a non-exclusive manner. For example, the intergovernmental agreement between Russia and Turkey includes provisions for plant construction, training and waste management, among others, so all of these categories were listed in the database for that agreement. If a cooperation unit explicitly included both concrete and supportive elements it was coded as belonging to both categories 5 . For the agreements compiled from Keeley's (2009b) list, we coded the agreement based on the database where it was clear from the title of the agreement. For example, an agreement titled "Nuclear Safety Agreement" would be coded as falling within the "Nuclear Safety" category. For agreements that did not contain sufficient details in Keeley's catalogue, we searched for the original source; if it was not accessible we coded the agreement as "Supportive with no further information".

Finally, we distinguished two modes of cooperation: directional and partnerships. This was important not only for categorizing the cooperation units, but also for determining the role actors play in different cooperation. In directional cooperation one country (supplier) provides technological support, nuclear materials or capacity building assistance to another country (client). This type of cooperation often involves nuclear newcomer ${ }^{6}$ countries importing equipment and expertise from countries with developed nuclear capabilities (Choi et al., 2009; e.g. Smith and Rose, 1989). In directional cooperation, a supplier country has more technological capabilities than the

\footnotetext{
${ }^{4}$ Strictly speaking, waste management is typically considered part of the nuclear fuel cycle. We consider it along with decommissioning because long-term waste management strategies are usually developed along with decommissioning strategies.

${ }^{5}$ In practice, virtually all concrete technological cooperation also implies supportive cooperation. For example, reactor supply normally includes some training. However, we only coded the cooperation as supportive if supportive elements were explicitly listed or named.

${ }^{6}$ We use the term 'Newcomer' for countries which are trying to introduce nuclear power.
} 
client or recipient country. Directional cooperation is signaled with wording such as "assistance" or "support". 7

Table 1 Coding categories for types of cooperation

\begin{tabular}{|c|c|c|}
\hline Categories & Sub-categories & Description \\
\hline \multicolumn{2}{|l|}{ Directional } & Supplier(s) and client(s) can be clearly identified \\
\hline \multicolumn{2}{|l|}{ Partnerships } & Supplier(s) and client(s) cannot be clearly identified \\
\hline \multicolumn{2}{|l|}{ Agreement } & A formally signed document was present \\
\hline \multicolumn{2}{|l|}{ Non-binding } & $\begin{array}{l}\text { Memorandum of Understanding or Joint Statement: No formally signed } \\
\text { agreement was identified }\end{array}$ \\
\hline \multicolumn{2}{|c|}{ Technological } & Related to nuclear technology and the nuclear fuel cycle \\
\hline \multicolumn{2}{|c|}{ Technological Concrete } & Material cooperation related to nuclear power \\
\hline & $\begin{array}{l}\text { Nuclear power plant } \\
\text { construction and } \\
\text { operation }\end{array}$ & $\begin{array}{l}\text { construction of, financing, maintenance and repairs of nuclear power } \\
\text { plants }\end{array}$ \\
\hline & Reactor supply & $\begin{array}{l}\text { supply of both nuclear reactors for power production, research or } \\
\text { maritime propulsion }\end{array}$ \\
\hline & Nuclear fuel cycle & $\begin{array}{l}\text { supply of enriched nuclear fuel or other material related to the fuel } \\
\text { cycle for nuclear power plants, including fuel fabrication, reprocessing, } \\
\text { and fuel plant construction }\end{array}$ \\
\hline & $\begin{array}{l}\text { Decommissioning } \\
\text { and waste } \\
\text { management }\end{array}$ & $\begin{array}{l}\text { nuclear power plant decommissioning and waste management as well } \\
\text { as nuclear waste handling procedures }\end{array}$ \\
\hline \multicolumn{2}{|c|}{ Technological Supportive } & Capacity development for nuclear power \\
\hline & $\begin{array}{l}\text { Knowledge } \\
\text { exchange and } \\
\text { training }\end{array}$ & $\begin{array}{l}\text { information exchange, training and capacity building, technology } \\
\text { transfer, intellectual property rights, academic or research cooperation, } \\
\text { local industry development }\end{array}$ \\
\hline & $\begin{array}{l}\text { Nuclear safety and } \\
\text { security }\end{array}$ & $\begin{array}{l}\text { safety measures to prevent accidents and security measures to guard } \\
\text { against nuclear material or fissile materials falling into the wrong hands }\end{array}$ \\
\hline & $\begin{array}{l}\text { Planning, regulation } \\
\text { and supportive } \\
\text { infrastructure }\end{array}$ & $\begin{array}{l}\text { planning and feasibility studies, developing and harmonizing regulation } \\
\text { and supportive infrastructure related to nuclear power plants and } \\
\text { materials }\end{array}$ \\
\hline & No information & cooperation units for which no additional information was available \\
\hline Uranium & & Mining operations usually for the purpose of uranium trade \\
\hline
\end{tabular}

\footnotetext{
${ }^{7}$ For example, in one agreement Ghana and Russia agree to bilateral cooperation in the "assistance in developing nuclear energy infrastructure in the Republic in Ghana” (technological concrete cooperation).
} 
If no clear directional relationship could be identified, the agreement was coded as a partnership.

Partnerships are common between two countries with similar technological capabilities or are signaled with wording such as 'exchange' or 'joint venture'. If there was no clear direction of capacity development, even if the two parties have different capabilities, the cooperation unit was coded as a partnership. ${ }^{8}$ In fact, much cooperation on nuclear safety relates primarily to exchange of information and thus was coded as 'Supportive Partnerships'.

\subsection{Coding roles of actors in cooperation}

The database record for each cooperation unit includes information about the participating countries and their roles. ${ }^{9}$ Each party to a directional cooperation unit was coded as 'supplier' or 'client'. Parties to non-directional agreements were coded as 'partners'. Where there were three partners involved in an agreement (so-called 'tri-partite' agreements), each bi-directional relationship was coded independently. ${ }^{10}$

Non-exclusive coding of cooperation units meant that in some agreements the same party was coded as both a supplier and a client. This was most common recorded in uranium-related agreements, many of which also involved directional technological cooperation. For example, Algeria and Russia have an agreement which covers planning for a nuclear power plant and uranium prospecting/mining development in Algeria, with Algeria potentially supplying uranium

\footnotetext{
${ }^{8}$ One example is a joint declaration between the UK and India to facilitate cooperation in various areas related to nuclear power including trade and research. Another example of a partnership agreement is an arrangement between Slovenia and Italy "for the early exchange of information in the event of a radiological emergency and cooperation in nuclear safety matters".

${ }^{9}$ This assumption is appropriate since in the majority of cases, nuclear cooperation agreements are between two states or state-owned companies. Even in countries where private corporations are involved in nuclear cooperation, their activities are often heavily regulated by the state. For example, in the US, companies can only cooperate with countries which have signed a '123 agreement' with the US.

${ }^{10}$ For example, in one agreement, Finland partnered with Russia to provide assistance to develop a nuclear power plant in Bulgaria. In this case, Russia and Finland were coded as supplier countries with Bulgaria as the client country, and Russia and Finland were coded as having a partnership cooperation.
} 
to Russia in the future. This agreement was coded as both a concrete technological cooperation unit (reactor and nuclear power plant construction) with Russia as the supplier and Algeria as the client, as well as a uranium cooperation unit with Algeria as the supplier and Russia as the client. ${ }^{11}$

\subsection{Data and network analysis}

To answer the first research question (What are the main types of international nuclear energy cooperation and how widespread is each type of cooperation?) we counted cooperation units that fall into each of the categories and sub-categories listed in Table 1. These categories also structured our analysis for the second and third questions, where we used both descriptive statistics and network analysis. Within the network analysis, countries (or jurisdictions) are nodes and cooperation units are links. Directional cooperation was represented by directed links and partnerships by undirected links. We analyzed four different networks independently: all technological nuclear cooperation units together, all technological supportive (both directional and partnerships), technological concrete directional, and technological concrete partnerships. Analyzing these networks separately allowed us to zoom-in on different types and modes of cooperation individually. The weights of the links were defined by adding the number of cooperation links signed between two countries. ${ }^{12}$

To answer the second research question (Which countries are the main actors in each type of international technological nuclear energy cooperation?) we calculated the prevalence of each country in different types and subtypes of cooperation. Additionally, for each of the networks, we calculated the number of countries a given country had cooperation with (the degree of the respective node) and the number of cooperation units in which a given country participated (weighted degree of the

\footnotetext{
${ }^{11}$ In the database these agreements are denoted with an " $\mathrm{A}$ " and a " $\mathrm{B}$ " at the end of the number.

12 Self-loops, i.e. when two or more different entities of the same country were parties to the same cooperation agreement, were not recorded. For example, in a few agreements, Areva and Électricité de France are joint suppliers. In these cases, the France-Client country relationship was only counted once in the network analysis and descriptive statistics.
} 
respective node). To identify the most the active suppliers and clients involved in directional cooperation we calculated out and in degree for each node (i.e. the number of directional links originating or ending in the node). We also calculated the net-degree, both weighted and unweighted: subtracting in-degrees of nodes from their out-degrees. This measure indicates whether the country is predominantly a supplier (positive net-degree) or a client (negative net-degree).

To analyze how central a particular country is in a particular type of cooperation we calculated the closeness centrality of each node. Closeness centrality is an indicator of how 'close' a country to all others, i.e. how easily it can 'reach' other nodes through connections (or links) in the network: the more central a country is, the closer it is to all other countries in the network (Freeman, 1978; Wasserman and Faust, 1994). It is calculated by taking the reciprocal of the sum of the shortest paths from the node to all other nodes of the network (see note to Table 2). With respect to nuclear cooperation it can, for example, signal how easily technologies from a supplier country can reach potential client countries or how easily intangible knowledge can be exchanged between partner countries. ${ }^{13}$

To answer the third question (What are the characteristics of the international nuclear energy cooperation network?) we measured the size (the number of nodes (countries), links (unique country pairs) and total sum of links (number of cooperation unit pairs) and density (the percentage of all possible connections between countries which are actually present in the network) of each network. We also calculated how many connected components there are in the network: do all nodes form a single connected network, or is it fragmented into two or more components? We also calculated

\footnotetext{
${ }^{13}$ We report and interpret this indicator for specific types of nodes and networks where it makes conceptual sense: for suppliers in the concrete technological networks, supportive technological networks and for all participants in the entire network. We do not report it for clients in concrete technologicalor concrete partnerships as in these cases this indicator is not meaningful because closeness to other nodes in the network does not necessarily mean access to different suppliers or partners.
} 
network level degree centralization of each network, which captures to what extent existing connections between countries are concentrated to one or more actor, or to say it in simple words, how big are the biggest actors - this metric approaches one in a star network with a single central actor and zero in a fully connected network where all nodes are interconnected (Freeman, 1978; Wasserman and Faust, 1994). The final measure used to evaluate the structure of a network is its average clustering coefficient. The clustering coefficient of individual nodes captures what share of their partners are also connected to each other forming triangles (triads). Averaging node level clustering for the whole network gives the average clustering coefficient of the whole network, thus giving an indication of the structure of the network (Wasserman and Faust, 1994). Before calculating density, closeness centrality and average clustering coefficient, we first converted each network into a symmetrical and binary network by removing link weights and link directions. ${ }^{14}$ Furthermore, isolated dyads (if they existed) were removed from the transformed (binary, undirected) networks to calculate closeness centrality.

\footnotetext{
${ }^{14}$ These undirected, binary networks only consider how many and which partners each country has. They do not take into consideration if the country is supplier or client, nor the number of agreements signed between two countries. Conceptually the existence of a single cooperation unit between two countries should suffice as a basis for future agreements, independent of the role that the countries play. This transformation also allowed us to investigate the question of centralization without the influence of the level of activity of individual actors. To calculate closeness centrality, isolates were removed.
} 
Table 2. Data and network metrics used to answer each research question.

Research question Data and Network metrics

RQ1. What are the main types of international nuclear energy cooperation and how widespread is each type of cooperation?

RQ2. Which countries are the main actors in each type of international nuclear energy cooperation?
RQ3. What are the characteristics of the international nuclear energy cooperation network?
Number of cooperation units within different categories and sub-categories

Degree metrics:

- $\quad$ degree $=$ number of partners

- $\quad$ in-degree $=$ number of suppliers

- $\quad$ out-degree $=$ number of clients

- $\quad$ net degree = out-degree minus in-degree

Weighted degree metrics:

- $\quad$ weighted degree $=$ number of cooperation links

- $\quad$ weighted in-degree $=$ number cooperation links in which the node is a client

- $\quad$ weighted out-degree = number cooperation links in which the node is a supplier

- $\quad$ net weighted degree $=$ weighted out-degree minus weighted in-degree

Closeness centrality = position within the network, how close they are to all other countries (scale: 0-1)*

Percentage of cooperation units of various categories where the country acts as a supplier, client or partner

Node count $=$ number of participating countries

Link count $=$ number of cooperation links in the network Density = how many links exist compared to the maximum possible number (scale: $0-1$ )

Connectedness $=$ number of connected components, one or more networks

Network-level degree centralization = to what extent are the existing connections concentrated to a few countries**

Average clustering coefficient $=$ to what extent do countries form triads***

Note: ${ }^{\star}$ Closeness centrality of the binary and undirected networks, after removing isolated dyads has been calculated with ORA-LITE (2018), based on Freeman (1978) as: let D be the distance network defined as: $D(i, j)=$ shortest path length from $i$ to $j$, and $D(i, i)=0$. The sum of shortest path lengths from node $i$ to all other nodes is $d$ $=\sum D i, j:$ for all nodes $\mathrm{j}$. And closeness centrality value for node $\mathrm{i}=(\mathrm{N}-1) / \mathrm{d}$.

** Degree centralization has been calculated with ORA-LITE (2018). Total degree centralization: let A be the input network with $\mathrm{N}$ nodes. Let $\mathrm{v}=$ vector of Total-Degree Centrality values for network $A$. Let $\mathrm{c}$ be the Centralization value for vector $\mathrm{v}$, which is a measure of the vector's spread or variability that is defined as the normalized sum of distances from the maximum value. Then Total-Degree Centralization $=c /(N-2)$. In- and out-degree centralization: let $A$ be the input network with $\mathrm{N}$ rows. Let $\mathrm{v}=$ vector of In/Out-Degree Centrality values for network $A$. Let $c$ be the centralization value for vector $v$, which is a measure of the vector's spread or variability that is defined as the normalized sum of distances from the maximum value. In/Out-Degree Centralization $=\mathrm{c} /(\mathrm{N}-1)$.

***Average clustering coefficient of the binary and undirected networks has been calculated ORA-LITE (ORA-LITE, 2018), based on Watts and Stogatz (1998): "averaging the clustering coefficient of each node, which is defined as the density of the node's ego network. [...] The ego network for node i consists of node $\mathrm{i}$ itself, all nodes directly connected to it, and the links between these nodes." (ORA-LITE, 2018)

Excel was used to generate link lists (of node to node relationships) which were then imported to

UCINET (Borgatti et al., 2002), ORA-LITE (ORA-LITE, 2018) and Gephi (Bastian et al., 2009) 
for analysis and visualization. Additional statistical calculations were carried out in Excel. The networks were visualized using the Force Atlas 2 layout algorithm of Gephi, which is an algorithm designed for networks characterized by a few highly connected nodes (Jacomy et al., 2014).

\section{Results}

\subsection{Types of international nuclear cooperation}

We identified 738 cooperation units related to international cooperation in the field of civilian nuclear power. A little less than half of these (325) were from Keeley's (Keeley, 2009a) list and the other half were from our own data collection.

We found evidence of an actually signed agreement in about 70\% (509) of the cooperation units; the remaining $30 \%$ were either memoranda of understanding or joint statements. Most cooperation units involved two countries; 14 agreements involved three countries. Approximately half of all cooperation units (360) contained directional elements and half (378) did not ${ }^{15}$, with almost all of the tripartite cooperation units having both a directional and a partnership component. These proportions were about the same with or without informal statements. Directional cooperation can be both concrete and supportive: for example, a supplier country assisting in building a nuclear power plant (concrete) or enhancing safety and security measures (supportive). Non-directional cooperation comes in many different forms: for example, between two established nuclear powers in setting up a national nuclear power program in a third country or between neighbors in building a joint nuclear infrastructure such as a nuclear power plant or

\footnotetext{
15 The sum of these two is greater than the total number of cooperation units because tripartite agreements often contain a partnership between two supplier countries and one client country (See Methods).
} 
waste management facility. Partnerships are usually supportive and only about $20 \%$ of partnerships involve concrete cooperation.

All in all, $252(34 \%)$ of cooperation units include concrete technological material aspects ${ }^{16}$; the other technological cooperation units only contain supportive elements. Nuclear power plant construction and operation and reactor supply are included in 15\% and 10\% of cooperation units respectively. Approximately $13 \%$ of cooperation units have provisions related to the nuclear fuel cycle (supply of nuclear fuel or related materials, fuel reprocessing or construction of reprocessing facilities). Another $9 \%$ of cooperation units include decommissioning and waste management. Only $67(9 \%)$ include cooperation in uranium exploration, mining or trade. Excluding non-binding changes each of these proportions by less than $3 \%$.

Many cooperation units with concrete elements also include provisions for supportive cooperation for knowledge exchange and capacity building. Such supportive elements are mentioned in 558 (about 76\%) cooperation units and range from research and training (included in $52 \%$ of all units) to nuclear safety and security (29\%) to planning, regulation and supportive infrastructure (14\%) (Table 3). Supportive cooperation is essential for nuclear newcomers who normally need transfer of technological and regulatory knowledge from countries with existing nuclear programs. Even countries without commercial nuclear power are involved in supportive cooperation related to research and nuclear safety.

\footnotetext{
${ }^{16}$ This does not include uranium-related cooperation (see Methods and Table 3).
} 
Table 3 The extent of different types of international nuclear cooperation

\begin{tabular}{lllll}
\hline Type of cooperation & \multicolumn{4}{l}{ Number of cooperation of each type } \\
\hline & All & \multicolumn{4}{l}{ Directional Partnerships Tri-partite } \\
\hline All agreements & $\mathbf{1 0 0 \% ( 7 3 7 )}$ & 346 & 377 & 14 \\
\hline Technological concrete & $\mathbf{3 4 \% ( 2 5 2 )}$ & 170 & 71 & 11 \\
\hline $\begin{array}{l}\text { Nuclear power plant Construction and } \\
\text { operation }\end{array}$ & $15 \%(11)$ & 86 & 18 & 7 \\
\hline Reactor supply & $10 \%(71)$ & 61 & 8 & 2 \\
\hline Nuclear fuel cycle & $13 \%(98)$ & 63 & 32 & 3 \\
\hline Decommissioning and waste management & $9 \%(64)$ & 35 & 28 & 1 \\
\hline Technological supportive & $\mathbf{7 5 \% ( 5 5 8 )}$ & 209 & 344 & 5 \\
\hline Knowledge exchange and training & $52 \%(384)$ & 142 & 240 & 2 \\
\hline Nuclear Safety and security & $29 \%(213)$ & 37 & 174 & 2 \\
\hline Planning, regulation \& supportive infrastructure & $14 \%(102)$ & 61 & 39 & 2 \\
\hline No information & $9 \%(63)$ & 39 & 24 & - \\
\hline Uranium & $\mathbf{9 \% ( 6 7 )}$ & 62 & 3 & 1 \\
\hline
\end{tabular}

Notes: The counts and percentages sum to more than $100 \%$ because the categories were coded in a non-exclusive manner.

\subsection{Main actors in international technological nuclear cooperation}

The full international technological nuclear cooperation network involves 83 countries and the European Union (EU) forming 355 country pairs. A total of 43 countries are suppliers in at least one cooperation unit, 65 countries are clients in at least one cooperation unit, and 69 countries are partners in at least one cooperation unit. ${ }^{17}$ The US and Russia dominate all types of cooperation: they have cooperation with the highest number of countries (degrees) and participate in the largest number of cooperation units (weighted degree). They are followed by France, China, Japan, Korea, India, Canada, Argentina and Ukraine. The US is best positioned to reach all other countries (it has the highest closeness centrality) closely followed by Russia, and less closely by France and

\footnotetext{
${ }^{17}$ The EU is a supplier in one agreement, a client in another and a partner in 18 agreements.
} 
Korea (Table 4). Virtually all countries with the exception of Niger and Venezuela participate in at least one non-uranium agreement.

Table 4. Numbers of cooperation partners and cooperation units and network position for the ten most active countries in international technological nuclear cooperation

\begin{tabular}{llll}
\hline Country & $\begin{array}{l}\text { Number of partner } \\
\text { countries (degree) }\end{array}$ & $\begin{array}{l}\text { Number of cooperation } \\
\text { units (weighted } \\
\text { degree) }\end{array}$ & $\begin{array}{l}\text { Network position } \\
\text { (closeness centrality) }\end{array}$ \\
\hline US & 55 & 178 & 0.76 \\
\hline Russia & 51 & 155 & 0.71 \\
\hline France & 39 & 107 & 0.65 \\
\hline China & 27 & 76 & 0.57 \\
\hline Japan & 24 & 76 & 0.55 \\
\hline Korea & 31 & 70 & 0.61 \\
\hline India & 16 & 51 & 0.53 \\
\hline Canada & 26 & 49 & 0.57 \\
\hline Argentina & 19 & 37 & 0.54 \\
\hline Ukraine & 17 & 34 & 0.52 \\
\hline
\end{tabular}

\subsubsection{Nuclear technology suppliers}

Only 17 countries and the EU are suppliers in at least one concrete technological agreement, and only six countries (Russia, US, France, China, Korea and Japan) account for $94 \%$ of suppliers in such agreements (Figure 2, Table 5). Russia is by far the largest technological supplier: in 81 (46\%) of all concrete technological agreements (Table 5), which is more than three times France and the US, the two next most active concrete technological suppliers. Russia supplies technology to 35 countries, which is more than twice as high as the country with the next highest number of national connections, France (16). Russia also dominates all sub-categories of concrete cooperation. These findings are robust to the inclusion or exclusion of non-binding cooperation statements. ${ }^{18}$ The only concrete form of cooperation where these six countries account for less than $80 \%$ of suppliers is decommissioning and waste, a less common type of cooperation mentioned only in 36

\footnotetext{
${ }^{18}$ Excluding these non-binding cooperation statements changes the percentages in the table by 3\% or less.
} 
directional agreements. Argentina is a supplier in four agreements (11\%): for three newcomers (UAE, Saudi Arabia, and Bolivia) and Australia in exchange for uranium supply.

Table 5 Main suppliers in concrete technological cooperation

\begin{tabular}{|c|c|c|c|c|c|c|c|c|c|c|}
\hline \multirow[b]{2}{*}{ Country } & \multicolumn{2}{|c|}{ Number of } & \multicolumn{2}{|c|}{$\begin{array}{l}\text { Participation in } \\
\text { cooperating links }\end{array}$} & \multicolumn{5}{|c|}{$\begin{array}{l}\% \text { of cooperation units where country } \\
\text { acts as supplier }\end{array}$} & \multirow{2}{*}{$\begin{array}{l}\text { Network } \\
\text { position } \\
\text { (closeness } \\
\text { centrality) }\end{array}$} \\
\hline & $\begin{array}{l}\text { Clients } \\
\text { (out- } \\
\text { degree) }\end{array}$ & $\begin{array}{l}\text { Suppliers } \\
\text { (in- } \\
\text { degree) }\end{array}$ & $\begin{array}{l}\text { As supplier } \\
\text { (weighted } \\
\text { out-degree) }\end{array}$ & $\begin{array}{l}\text { As client } \\
\text { (weighted } \\
\text { in-degree) }\end{array}$ & $\begin{array}{l}\text { All } \\
\text { concrete } \\
\text { technol. }\end{array}$ & $\begin{array}{l}\text { Construct. } \\
\text { \& operation }\end{array}$ & $\begin{array}{l}\text { Reactor } \\
\text { supply }\end{array}$ & $\begin{array}{l}\text { Fuel } \\
\text { cycle }\end{array}$ & $\begin{array}{l}\text { Decomiss. } \\
\& \text { waste }\end{array}$ & \\
\hline Russia & 35 & 1 & 81 & 1 & $46 \%$ & $53 \%$ & $51 \%$ & $48 \%$ & $53 \%$ & 0.72 \\
\hline France & 16 & 1 & 23 & 1 & $13 \%$ & $11 \%$ & $6 \%$ & $14 \%$ & $11 \%$ & 0.55 \\
\hline US & 11 & 0 & 18 & 0 & $10 \%$ & $6 \%$ & $6 \%$ & $11 \%$ & $8 \%$ & 0.44 \\
\hline China & 10 & 5 & 17 & 14 & $10 \%$ & $9 \%$ & $13 \%$ & $11 \%$ & $3 \%$ & 0.56 \\
\hline Korea & 13 & 0 & 15 & 0 & $8 \%$ & $10 \%$ & $11 \%$ & $3 \%$ & $3 \%$ & 0.43 \\
\hline Japan & 9 & 3 & 14 & 3 & $8 \%$ & $10 \%$ & $2 \%$ & $6 \%$ & $0 \%$ & 0.49 \\
\hline $\begin{array}{l}\text { All } \\
\text { others }\end{array}$ & - & & - & & $12 \%$ & $9 \%$ & $11 \%$ & $8 \%$ & $25 \%$ & - \\
\hline
\end{tabular}

Note: The table includes the six most active supplier countries accounting suppliers in over $90 \%$ of cooperation units containing a concrete technological supply element.

The largest supplier, Russia also has the highest closeness centrality, meaning that it is 'closer' in network terms to the other countries which may mean more countries readily have access to Russian technology. It is followed by China, France and the UK Interestingly, two of the largest suppliers (Korea and the US) have fairly low closeness centrality $\left(29^{\text {th }}\right.$ and $22^{\text {nd }}$ respectively); this is because they are not connected to Russia which are central in the concrete technological network and connected to most other nodes.

\subsubsection{Nuclear technology clients}

India, China, Bulgaria and Ukraine are the most active clients in concrete technological cooperation (Table 6). The most active client countries except for Pakistan have several suppliers (in-degree). For example: Jordan, Turkey, the UAE and Saudi Arabia all have 8-9 cooperation links with 6 suppliers. Our analysis also shows that most countries serve primarily as either a supplier 
or a client. This can be seen by comparing Table 5 and Table 6 . The countries where this is not the case are China (supplier in 17 and client in 14 agreements), Argentina (supplier in 5 and client in 5) and the UK (supplier in 3 and client in 5).

Table 6. Main clients in concrete technological cooperation

\begin{tabular}{|c|c|c|c|}
\hline Country & $\begin{array}{l}\text { Number of suppliers } \\
\text { (in-degree) }\end{array}$ & $\begin{array}{l}\text { Number of cooperation } \\
\text { links (weighted in-degree) }\end{array}$ & $\begin{array}{l}\% \text { of units where the country is a } \\
\text { client (directional concrete) }\end{array}$ \\
\hline India & 3 & 16 & $9 \%$ \\
\hline China & 5 & 14 & $8 \%$ \\
\hline Bulgaria & 4 & 10 & $6 \%$ \\
\hline Ukraine & 3 & 10 & $6 \%$ \\
\hline Jordan & 6 & 9 & $5 \%$ \\
\hline Kazakhstan & 3 & 8 & $4 \%$ \\
\hline Turkey & 6 & 8 & $4 \%$ \\
\hline UAE & 6 & 8 & $4 \%$ \\
\hline Vietnam & 4 & 7 & $4 \%$ \\
\hline Armenia & 3 & 6 & $3 \%$ \\
\hline Pakistan & 1 & 6 & $3 \%$ \\
\hline Saudi Arabia & 6 & 6 & $3 \%$ \\
\hline South Africa & 3 & 6 & $3 \%$ \\
\hline All others & - & $\leq 5$ & $\leq 3 \%($ total $42 \%)$ \\
\hline
\end{tabular}

Note: The table excludes countries which are a client in five or less concrete technological cooperation links. It thus shows the 13 most active clients which account for over half of clients in concrete directional cooperation.

\subsubsection{Partners in concrete technological cooperation}

The five countries with the most concrete partnerships (highest weighted degree), Russia, France, Japan, the US and Korea (Table 5), are also among the top 6 suppliers in concrete technological cooperation (Table 7). Additionally, 8 countries and the EU participate in at least 5 concrete partnerships. 
Table 7 Main participants in concrete technological partnerships

\begin{tabular}{|c|c|c|c|c|c|c|c|}
\hline \multirow{2}{*}{ Country } & \multirow{2}{*}{$\begin{array}{l}\text { Number of } \\
\text { national } \\
\text { partners } \\
\text { (degree) }\end{array}$} & \multirow{2}{*}{$\begin{array}{l}\text { Number of } \\
\text { concrete } \\
\text { partnerships } \\
\text { (weighted } \\
\text { degree) }\end{array}$} & \multicolumn{5}{|c|}{$\%$ of cooperation units where acts as a partner } \\
\hline & & & $\begin{array}{l}\text { All } \\
\text { concrete }\end{array}$ & $\begin{array}{l}\text { Construction \& } \\
\text { operation }\end{array}$ & $\begin{array}{l}\text { Reactor } \\
\text { supply }\end{array}$ & $\begin{array}{l}\text { Fuel } \\
\text { cycle }\end{array}$ & $\begin{array}{l}\text { Decomiss. \& } \\
\text { waste }\end{array}$ \\
\hline Russia & 15 & 24 & $30 \%$ & $36 \%$ & $13 \%$ & $29 \%$ & $24 \%$ \\
\hline France & 8 & 19 & $23 \%$ & $32 \%$ & $38 \%$ & $9 \%$ & $28 \%$ \\
\hline Japan & 7 & 16 & $20 \%$ & $16 \%$ & $0 \%$ & $18 \%$ & $28 \%$ \\
\hline US & 6 & 14 & $17 \%$ & $16 \%$ & $0 \%$ & $12 \%$ & $28 \%$ \\
\hline Korea & 5 & 8 & $10 \%$ & $16 \%$ & $13 \%$ & $15 \%$ & $7 \%$ \\
\hline EU & 7 & 7 & $9 \%$ & $0 \%$ & $0 \%$ & $12 \%$ & $14 \%$ \\
\hline Ukraine & 5 & 7 & $9 \%$ & $0 \%$ & $0 \%$ & $18 \%$ & $3 \%$ \\
\hline Canada & 6 & 6 & $7 \%$ & $0 \%$ & $0 \%$ & $18 \%$ & $0 \%$ \\
\hline UK & 4 & 6 & $7 \%$ & $8 \%$ & $13 \%$ & $0 \%$ & $10 \%$ \\
\hline Argentina & 3 & 5 & $6 \%$ & $4 \%$ & $13 \%$ & $12 \%$ & $3 \%$ \\
\hline Brazil & 3 & 5 & $6 \%$ & $4 \%$ & $25 \%$ & $9 \%$ & $3 \%$ \\
\hline China & 3 & 5 & $6 \%$ & $16 \%$ & $38 \%$ & $3 \%$ & $0 \%$ \\
\hline Finland & 4 & 5 & $6 \%$ & $12 \%$ & $0 \%$ & $0 \%$ & $7 \%$ \\
\hline India & 4 & 5 & $6 \%$ & $0 \%$ & $0 \%$ & $9 \%$ & $7 \%$ \\
\hline
\end{tabular}

Note: Excludes countries with less than 5 concrete technological partnerships.

This group includes the other one of the biggest suppliers (China), three countries operating nuclear fleets for over two decades (Canada, the UK, and Finland), two of the main client countries (India and Ukraine) and Brazil and Argentina which have three agreements between each other related to the construction of a joint nuclear power plant. The EU is another major player in the concrete technological partnerships providing financing and support for decommissioning as well as fuel cycle and nuclear waste services, particularly in Eastern Europe. 


\subsubsection{Participants in supportive technological cooperation}

Within purely supportive cooperation, countries involved in most cooperation units (highest weighted degree) are the same as the top six suppliers in concrete technological cooperation plus Canada. The US is the most active in supportive cooperation (weighted degree: 146), participating in $39 \%$ of non-concrete cooperation units with a Knowledge and training component and $52 \%$ of cooperation units with a Safety and security component. The US' leadership in supportive cooperation may be linked to its historical dominance as a technology supplier and could in the future be eroded as Russia and other technology suppliers become more dominant. ${ }^{19}$ In contrast, Russia participates in only 11\% of purely supportive cooperation units (weighted degree: 49). In addition to the top six suppliers of concrete technological cooperation are three nuclear veterans (Argentina, Canada, and the Czech Republic) and one of the most active clients (India). There are only five countries in our dataset that do not participate in supportive technological cooperation: Bolivia, Myanmar, Niger, Senegal and Venezuela. This could signal either very early stages of or a lack of seriousness about pursuing nuclear power. Senegal and Venezuela canceled their nuclear power programs after the Fukushima accident (Rogner, 2013).

\footnotetext{
${ }^{19}$ For a discussion of the US' historic leadership in setting nuclear safety and security standards and its link to its role as technology supplier see Saha (2017).
} 
Table 8 Main participants in purely supportive technological cooperation

\begin{tabular}{|c|c|c|c|c|c|c|c|c|}
\hline \multirow[b]{2}{*}{ Country } & \multirow[b]{2}{*}{$\begin{array}{l}\text { Number } \\
\text { of } \\
\text { partners } \\
\text { (degree) }\end{array}$} & \multirow{2}{*}{$\begin{array}{l}\text { Number of } \\
\text { supportive } \\
\text { cooperation } \\
\text { links } \\
\text { (weighted } \\
\text { degree) }\end{array}$} & \multicolumn{5}{|c|}{$\%$ of cooperation units where acts as a participant } & \multirow[b]{2}{*}{$\begin{array}{l}\text { Network } \\
\text { position } \\
\text { (closeness } \\
\text { centrality) }\end{array}$} \\
\hline & & & $\begin{array}{l}\text { Only } \\
\text { supportive } \\
\text { cooperation }\end{array}$ & $\begin{array}{l}\text { Knowledge } \\
\text { exchange } \\
\text { \& training }\end{array}$ & $\begin{array}{l}\text { Nuclear } \\
\text { safety \& } \\
\text { security }\end{array}$ & $\begin{array}{l}\text { Planning } \\
\& \\
\text { regulation }\end{array}$ & $\begin{array}{l}\text { No } \\
\text { information }\end{array}$ & \\
\hline US & 52 & 146 & $33 \%$ & $39 \%$ & $53 \%$ & $27 \%$ & $10 \%$ & 0.75 \\
\hline France & 30 & 64 & $14 \%$ & $18 \%$ & $11 \%$ & $10 \%$ & $18 \%$ & 0.61 \\
\hline Russia & 37 & 49 & $11 \%$ & $8 \%$ & $7 \%$ & $14 \%$ & $19 \%$ & 0.63 \\
\hline Korea & 21 & 47 & $11 \%$ & $10 \%$ & $6 \%$ & $6 \%$ & $16 \%$ & 0.56 \\
\hline Japan & 17 & 44 & $10 \%$ & $11 \%$ & $10 \%$ & $8 \%$ & $0 \%$ & 0.53 \\
\hline Canada & 25 & 42 & $9 \%$ & $10 \%$ & $4 \%$ & $24 \%$ & $0 \%$ & 0.56 \\
\hline China & 20 & 41 & $9 \%$ & $8 \%$ & $5 \%$ & $3 \%$ & $21 \%$ & 0.53 \\
\hline India & 14 & 29 & $7 \%$ & $5 \%$ & $3 \%$ & $7 \%$ & $11 \%$ & 0.52 \\
\hline Argentina & 13 & 22 & $5 \%$ & $6 \%$ & $6 \%$ & $4 \%$ & $2 \%$ & 0.51 \\
\hline Czech Rep. & 11 & 21 & $5 \%$ & $6 \%$ & $9 \%$ & $4 \%$ & $2 \%$ & 0.51 \\
\hline
\end{tabular}

Note: Includes countries which participate in at least 20 supportive cooperation links or $5 \%$ of all supportive units.

The countries with the most connections (highest weighted degree) are the same as those with the highest closeness centrality scores. The US is closest to all other countries in the network, followed by Russia and France.

\subsection{Characteristics of the international technological nuclear cooperation network}

The network of all cooperation units (Figure 1, Table 9) forms a single connected component that involves 84 jurisdictions ${ }^{20}$ (nodes) and 342 unique country pairs (links). Japan and the US have the most agreements together (highest link weight of 20). The network has a density of 0.103 meaning

\footnotetext{
${ }^{20}$ Eighty-three countries and the European Union (EU).
} 
that around $10 \%$ of all possible connections are present, however these connections are concentrated around a few actors (degree centralization is 0.59 ).

Figure 1 Aggregate network of all international technological nuclear cooperation units

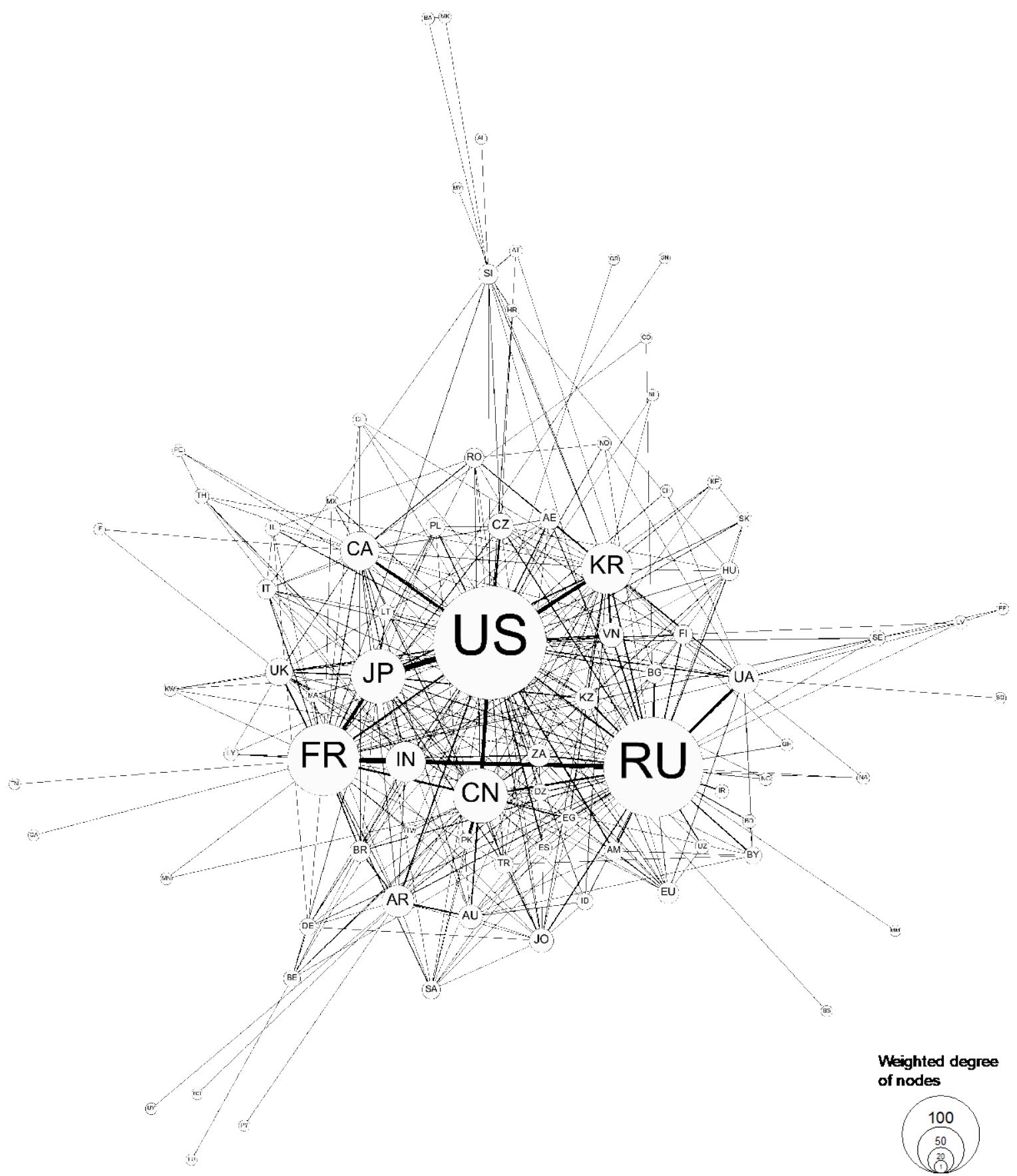

Note: Layout by Gephi Force Atlas 2 algorithm (see Methods). The size of each node is determined by the number of cooperation units the country has signed (weighted degree). All connections are mapped as undirected. Links are scaled according to the number of cooperation units between the countries (link weight). 
The network of all nuclear cooperation shown in Figure 1 can be disaggregated into four networks by type of cooperation. The characteristics of these networks are listed in Table 9 and discussed in the next four subsections.

Table 9. Characteristics of the aggregate and individual technological nuclear cooperation networks

\begin{tabular}{|c|c|c|c|c|}
\hline \multirow{3}{*}{ Directional } & \multirow{3}{*}{$\begin{array}{l}\begin{array}{l}\text { Full } \\
\text { Network }\end{array} \\
\text { No }\end{array}$} & \multicolumn{2}{|l|}{ Concrete } & \multirow[t]{2}{*}{ Supportive } \\
\hline & & Directional & Partnerships & \\
\hline & & Yes & No & $\mathrm{No}^{*}$ \\
\hline Participating countries (Number of nodes) & 84 & 55 & 36 & 79 \\
\hline Number of cooperation pairs (links) & 342 & 115 & 57 & 266 \\
\hline $\begin{array}{l}\text { Number of cooperation links (Total sum of } \\
\text { weighted links) }\end{array}$ & 719 & 189 & 83 & 450 \\
\hline $\begin{array}{l}\text { Highest number of links between two } \\
\text { countries (Highest link weight) }\end{array}$ & 20 & 10 & 6 & 13 \\
\hline Countries with highest link weight & Japan-US & Russia-India & Japan-US & Japan-US \\
\hline Number of components & 1 & 1 & 2 & 1 \\
\hline Isolates & na & na & $\begin{array}{l}\text { Croatia- } \\
\text { Slovenia }\end{array}$ & na \\
\hline Density (unweighted, directed) & na & 0.039 & na & na \\
\hline Density (unweighted, undirected) & 0.103 & 0.076 & 0.09 & 0.086 \\
\hline $\begin{array}{l}\text { Out-degree centralization (unweighted, } \\
\text { directed) }\end{array}$ & na & 0.621 & na & na \\
\hline $\begin{array}{l}\text { In-degree centralization (unweighted, } \\
\text { directed) }\end{array}$ & na & 0.074 & na & na \\
\hline $\begin{array}{l}\text { Degree centralization (unweighted, } \\
\text { directed) }\end{array}$ & na & 0.306 & na & na \\
\hline $\begin{array}{l}\text { Undirected degree centralization } \\
\text { (unweighted, undirected) }\end{array}$ & 0.590 & 0.613 & 0.358 & 0.595 \\
\hline $\begin{array}{l}\text { Average clustering coefficient } \\
\text { (unweighted, undirected) }\end{array}$ & 0.574 & 0.251 & 0.171 & 0.503 \\
\hline
\end{tabular}

Notes: *Directional cooperation links in this network were converted to un-directional for the network analysis, see section 2.4 . 


\subsubsection{Concrete directional technological cooperation}

Fifty-five countries involved in concrete directional technological cooperation form a single network with 113 unique country pairs and 189 cooperation links ${ }^{21}$ (sum of weighted links). The most cooperation links are between Russia and India (10). There are two bi-directional links: between Kazakhstan and Japan, and France and India. ${ }^{22}$

The density of the network is 0.076 (unweighted, undirected), which is the lowest among the examined networks (Figure 2, Table 9). The suppliers of concrete technological cooperation are highly centralized: out-degree centralization is 0.621 as compared to in-degree centralization of clients which is merely 0.074 . The average clustering coefficient of the network is merely 0.251 , meaning that its local structure is more like a star-like network, with only $20 \%$ of a country's partners being connected also to each other.

\footnotetext{
${ }^{21}$ We use the term cooperation link to distinguish between cooperation unit because a cooperation unit can involve three parties whereas a cooperation link can only involve two.

${ }^{22}$ In the agreement where Kazakhstan is a supplier to Japan, Kazakhstan agrees to supply part of the nuclear fuel for one of Japan's nuclear reactors. In the agreement where India is a supplier to France, India agrees to partially finance a French nuclear power plant.
} 
Figure 2 Network of supplier and client countries formed by directional concrete technological cooperation units
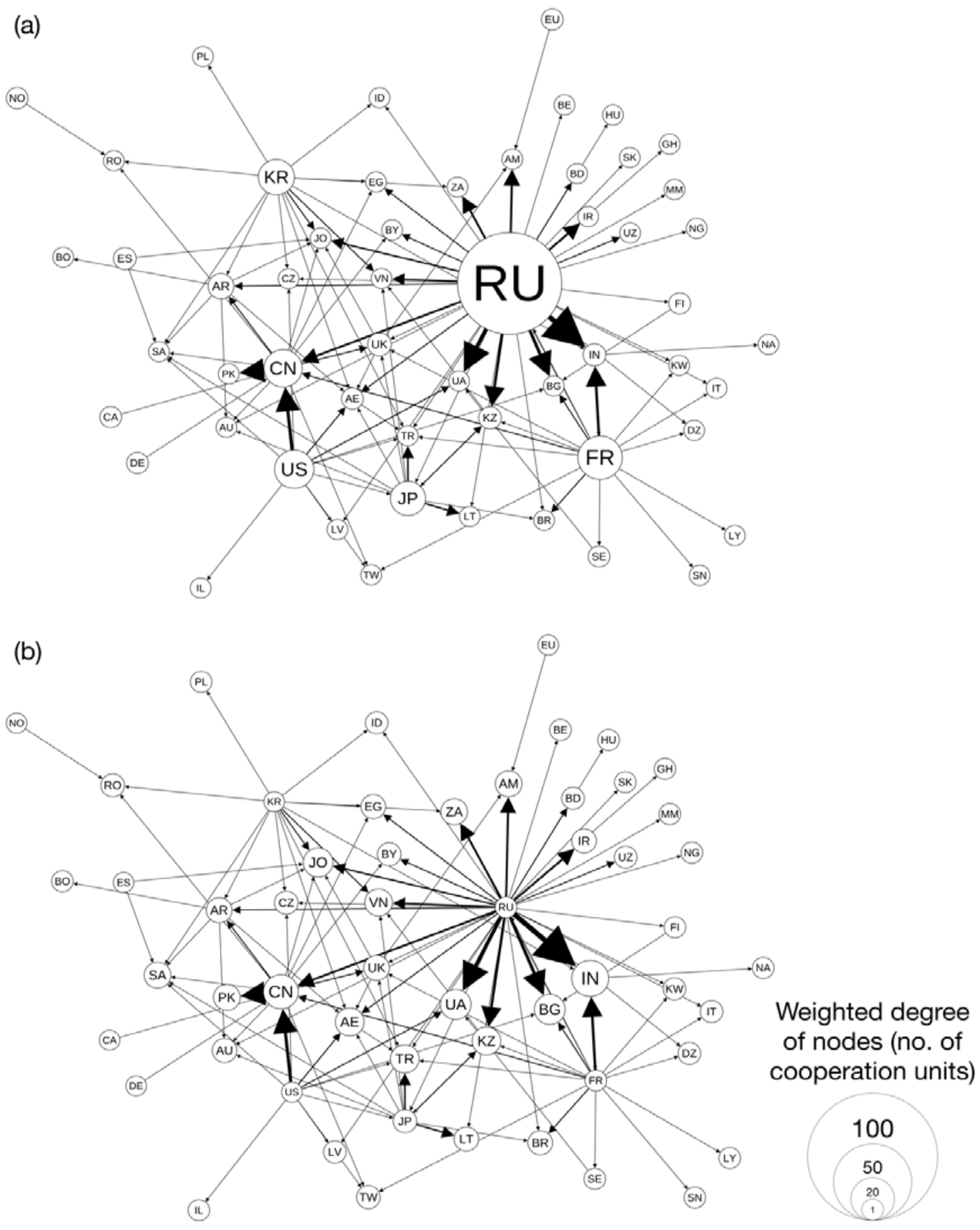

Notes: Layout by Gephi Force Atlas 2 algorithm (see Methods). In panel (a), each node is scaled by its activity as a supplier in directed concrete technological cooperation units (weighted out-degree); in panel (b), each node is scaled by its activity as a client in directed concrete technological cooperation units (weighted in-degree). Links are scaled according to the number of directed concrete technological cooperation links between the countries (link weight). 


\subsubsection{Concrete technological partnerships}

Thirty-six countries (nodes) form this network consisting of 57 country pairs (links) connected through 83 cooperation links. The network has a large component (34 nodes) and an isolated dyad of Croatia and Slovenia (which jointly operate a nuclear power plant located in Slovenia and which supplies a large share of Croatia's electricity). The largest number of partnerships (6) is between Japan and the US (Figure 3, Table 9). The overall distribution of concrete partnerships is robust against including or excluding non-binding types of cooperation and changes the distribution by less than two percentage points. ${ }^{23}$

\section{Figure 3. Network of countries formed by concrete technological partnerships}

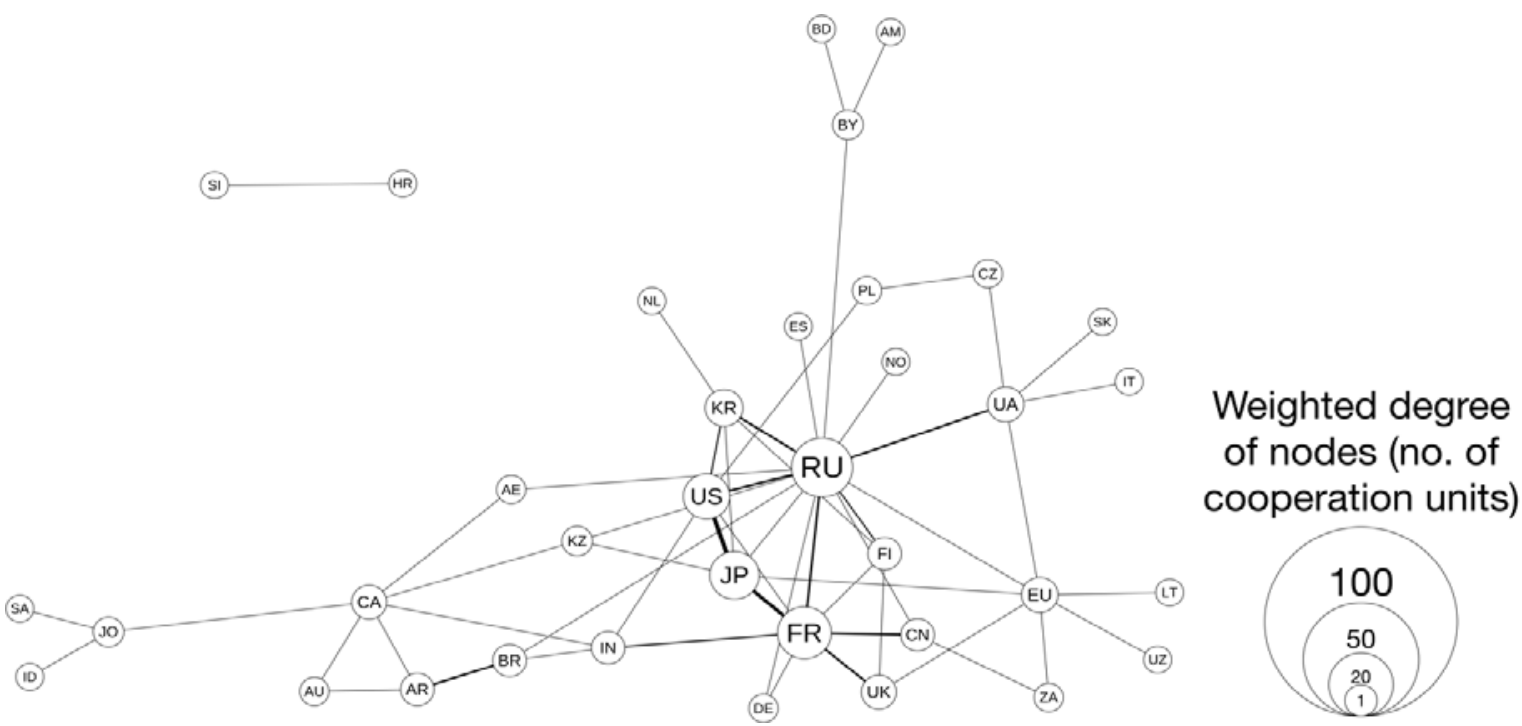

Note: Layout by Gephi Force Atlas 2 algorithm (see Methodology). The size of each node is scaled by the number of concrete technological partnerships the country has signed (weighted degree). Links are scaled according to the number of concrete technological partnerships between the countries (link weight).

Centralization of the concrete technological partnerships is lower than the directional relationships: degree centralization is 0.358 , meaning that the cooperation links are less

\footnotetext{
${ }^{23}$ However, the distribution between countries within each subcategory is sensitive to the inclusion or exclusion of non-binding statements. This is mostly due to the fact that there are relatively fewer concrete partnerships than other types of cooperation thus a few cooperation units can affect the distribution by up to 15 percentage points. Most notably, removing non-binding statements increases Russia's dominance in Construction and operation by 10 percentage points and decreases Korea's proportion by 13 percentage points.
} 
concentrated around a few actors. Its clustering coefficient, on the other hand, is low averaging at 0.171, indicating a local structure around nodes that are star-like.

\subsubsection{Supportive cooperation}

The 450 cooperation links of purely supportive cooperation form a network that involve 79 countries (nodes), that form 266 unique country pairs (links) in a single connected network. The highest number of agreements (link weight) is 13 between Japan and the US The density of the network is 0.086 (Table 9, Figure 4). The distribution of main actors in all supportive cooperation is robust to the exclusion of non-binding cooperation and changes the distribution between the top participants by less than $5 \%$. However, for the sub-categories, excluding non-binding statements increases the US' dominance in safety and security, knowledge and training and planning and regulation by about 20 percentage points which reflects the country's seriousness about in engaging in cooperation related to safety and security. It also increases Russia and Canada's dominance in planning and regulation by 11 and 18 percentage points respectively.

This network is highly centralized: its degree centralization is 0.595 , indicating that most cooperation units are concentrated around a few major actors, see also Table 8 . The average clustering coefficient of countries in supportive technological cooperation (0.503), is much higher than for other types of cooperation. This means that, on average, more than half of each countries' partners are also connected to each other. Intuitively, it makes sense: countries more easily form supportive cooperation links which are not constrained by their 'hard' technological capabilities. The flow of knowledge is easier than the flow of equipment, infrastructure and finance. 


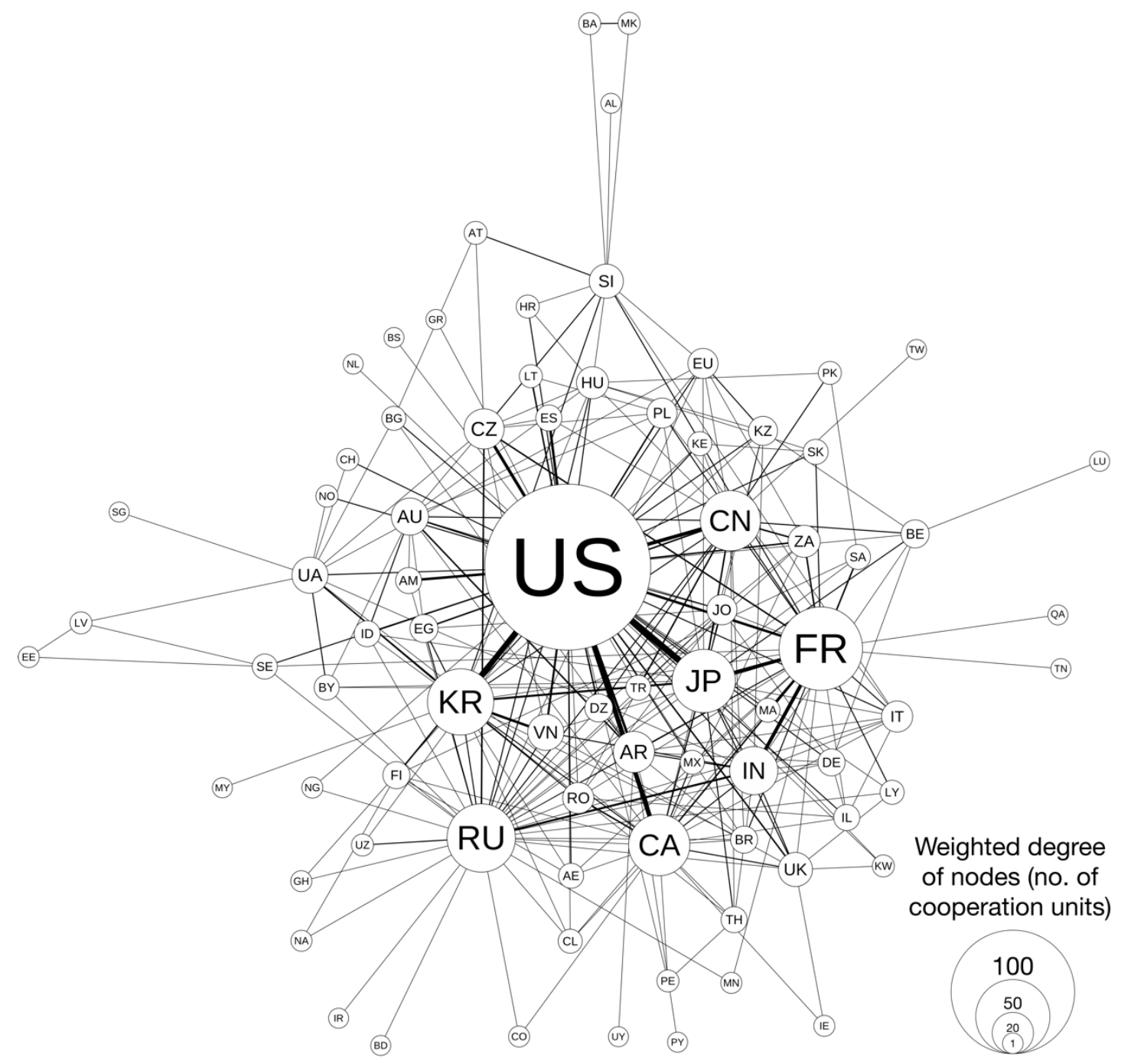

Note: Layout by Gephi Force Atlas 2 algorithm (see Methods). The size of each node is determined by the number of supportive technological partnerships the country has signed (weighted degree). Links are scaled according to the number of supportive technological partnerships between the countries (link weight).

\section{Limitations and avenues for further research}

There are a number of limitations to our approach which should be addressed with further research. Using reports of cooperation agreements as a proxy for international activity has the potential to under-sample cooperation between private companies and cooperation which is less publicized. This approach is also unable to distinguish between agreements which are likely to go ahead and those which may be simply signed for prestige or strategic reasons. To understand the 
extent of these limitations, this database could be supplemented with a detailed case study of a handful of country-pairs to see how frequently nuclear cooperation agreements are signed by private companies without government-to-government activity and to quantify the relationship between supportive and concrete cooperation as well as to estimate the percentage of agreements which are signed for purely symbolic reasons. Those clients in advanced stages of planning new nuclear power programs, such as Turkey, UAE, and Vietnam would be prime candidates for this analysis.

Another promising direction of future research is to explore the time dynamics of nuclear cooperation. Our sampling approach focuses on the period 2000-2015 from a number of established databases and targeted online searches (see section 2.1). While this sampling approach is appropriate for our research question which focuses on which actors and arrangements will shape the future of nuclear energy, it probably under-samples routine on-going cooperation, particularly between established partners who do not have nuclear power expansion plans. This approach also does not account for the expiration of agreements nor how agreements may change over time. Expanding the sample period would open the door for a wider range of research questions. For example, how has international nuclear cooperation changed over time and how has it been affected by the privatization of the nuclear industry in some countries?

Using time series analysis, would also make it possible to explore at questions such as how many years after importing nuclear technologies it takes a country able to become a supplier. ${ }^{24}$ This would give more insight into when China and India may be able to export nuclear technologies. Combining time series analysis with more granular analysis of cooperation with private firms (if such data could be obtained from the historical record), it would be possible to explore when US

\footnotetext{
24 This would expand earlier work from Choi et al. (2009) about the length of time it takes to 'localize' a nuclear industry to how long it takes to export that industry.
} 
firms lost their dominance as nuclear exporters. It would also make it possible to explore whether nuclear suppliers played a role in the different cost trajectories observed in countries with nuclear power (Loevering et al. 2016; Koomey et al. 2016; Grubler 2010) Finally, it would be good to compare the top suppliers in our dataset to see whether their nuclear export strategy changed after Fukushima.

It would also be possible to expand the network analysis. Using network analysis to understand international networks has a long tradition with three main types of analysis: to identify clusters or neighborhoods of countries using data such as on trade or membership in international organizations; to test world-systems theory or the theory that many factors which influence a nation state's development are exogenous to that state (and belong to the "world system"); and more recently to explore key questions in international relations and political science (Nordlund, 2011). Our use of network analysis is closest to the first tradition to gain insights into the nature and geography of an international network. We do not position our research to either extend or test world-systems theory or key IR theories though the dataset we present could potentially also be used to test hypotheses in those literatures. There are two particularly promising avenues in this regard. On the one hand, using a longer time series analysis, would make it possible to see how the network has evolved overtime and how different technologies move through the network. Another promising area is to expand the analysis as to why supplier states cooperate in the first place which could build on work by both Fuhrmann (2009) and Lantis (2014) who explore this question.

\section{Conclusion and policy implications}

While nuclear energy plays an important role in energy, its international political economy remains much less researched and understood than international political economy of other energy sources, 
particularly oil and gas. Our study addresses this gap by building and systematically analyzing a comprehensive dataset of 738 recent international civil nuclear agreements and non-binding statements of cooperation between 84 jurisdictions. In addition to descriptive statistics, we use network science methods, a tool for studying international cooperation.

\subsection{Summary of findings}

We find evidence of significant international cooperation in all types of international technological nuclear cooperation, including construction and operation of nuclear power plants, manufacturing of nuclear reactors, production of nuclear fuel, decommissioning and waste management, and supply of uranium (Table 3). Such tangible material elements feature in over $40 \%$. A related observation is that about $60 \%$ cooperation does not include any material aspects, but instead covers regulatory and knowledge-exchange provisions, especially in the field of nuclear safety and security. Since such provisions also feature in many agreements with concrete material elements, this type of 'supportive' cooperation is clearly the most widespread form of international technological nuclear cooperation.

Our analysis confirms earlier findings (Brutschin and Jewell, 2018; Cherp et al., 2012) that despite the large number of countries involved in international technological nuclear cooperation it is dominated by only a handful of countries, most notably Russia and the US. However, the main nuclear suppliers and clients somewhat differ across different types of cooperation. To begin with, only six countries (Russia, France, the US, China, Korea and Japan) are suppliers in over 90\% of all agreements with concrete technological elements, with Russia being a supplier in $46 \%$ of all such agreements and in over 50\% of agreements concerning nuclear power plant construction and nuclear reactors. The same six countries are also involved in the largest number of concrete technological partnerships and supportive cooperation (e.g. knowledge and regulations). However, the US, rather than Russia is the most active participant in supportive cooperation: it is involved 
in one-third of all supportive agreements and more than one-half of cooperation concerned with safety and security.

The dominance of Russia in international technological nuclear cooperation has been observed by other authors. A recent article in Foreign Affairs calls attention to the fact that Russia has 34 reactorsupply deals worth about $\$ 300$ billion, making up about $60 \%$ of the global reactor market (Galluci and Schellenberger, 2017). This figure is remarkably close to our finding that Russia is a supplier in over $50 \%$ of reactor agreements. What we also find is that in addition to reactor supply, Russia dominates agreements related to construction and operation of nuclear power plants, the fuel cycle and waste management. Lantis (2014) argued that both strategic and economic considerations (especially diversifying hard currency earnings from gas and oil revenues) may be behind Russia's interest in exporting nuclear technology and that it is difficult for other countries to compete with state-owned Russian companies for international markets. It is not uncommon for Russia to offer comprehensive deals including financing and training as part of its reactor supply and nuclear power plant construction. Such deals are made possible by a well-coordinated network of stateowned subsidiaries of Atomenergoprom (led by Rosatom), which has offices in over 60 countries (ROSATOM, 2016). This may be especially attractive for newcomers such as Turkey (Jewell and Ates, 2015) and Belarus which have signed intergovernmental agreements with Russia under which Russia will pay for, build and operate the nuclear power plants in exchange for a guaranteed electricity price for a fixed number of years.

Russia is a supplier in more nuclear technology agreements than the four next largest suppliers (France, US, China and Korea) combined. American companies have comparable technological capabilities to Russia, but as Lantis (2014) points out, American companies not only lack comparable state-backing but also can only cooperate with countries which have signed the 123 agreement. This restriction requires client countries to limit nuclear activities in exchange for the 
right to purchase equipment from American firms. The recent bankruptcy of Westinghouse may signal further weakening the US position on the global nuclear market (Galluci and Schellenberger, 2017). The question is whether the decline of the US' technological dominance will also lead to an erosion of its role in supportive and capacity building cooperation. ${ }^{25}$ Although Lantis (2014) found evidence of a 'race' for clients between Russia and Japan and Cherp et al. (2017) point to Japanese corporations actively acquiring overseas nuclear technology assets in the 2000s, our analysis does not identify Japan as a particularly active supplier.

China is a supplier in only $11 \%$ of concrete technological agreements, though it is pursuing a strategy to export nuclear technology (WNA, 2016b; Wübbeke and Ting, 2016). With its stateowned centralized nuclear power industry and deep pockets, China could potentially compete with Russia as a supplier. Even though most of their fleet has been built with imported technologies, Chinese firms are now working on advanced reactor designs which they hope to export. India also emerges as an interesting case as the largest client in both concrete and supportive cooperation. This is probably due to two reasons: plans for expanding its own nuclear power to and a strategy of strengthening its domestic industry to eventually become an exporter. India has a handful of domestically produced nuclear power plants and is actively pursuing both technological and political developments which would enable it to become a major exporter (WNA, 2016c).

The clients of nuclear technology are less concentrated than suppliers (the six largest clients account for only $32 \%$ of the agreements), a fact that further solidifies the power of major suppliers. While suppliers are mostly industrialized countries with large and older domestic nuclear power fleets, the main nuclear technology clients are dominated by nuclear newcomers, i.e. countries interested in launching national nuclear programs (Vietnam, Jordan, Saudi Arabia, Egypt, UAE,

\footnotetext{
${ }^{25}$ For a discussion of the US' historical leadership in defining and global nuclear safety and security standards see Saha (2017).
} 
Algeria, Turkey and Kazakhstan). The International Atomic Energy Agency (IAEA) assumes that all nuclear newcomers will initially import the technology and features the readiness to invite international bids as a milestone to introducing nuclear power (IAEA, 2015) which underlines the centrality of international technological cooperation in national plans to launch nuclear power programs. It's possible that the level of client activity could be an indication of seriousness regarding the pursuit of nuclear energy.

Our network analysis identifies a somewhat different structure of international technological nuclear cooperation networks depending on the type of cooperation. The concrete technological nuclear cooperation network is fairly centralized with few dominant actors and 'star-like' structures, whereas the network of supportive cooperation is less centralized and more 'mesh-like'. This means that knowledge and regulatory procedures (which are obviously less constrained by 'hard' financial and technological capabilities) can more freely flow between countries, not necessarily involving major hubs such as Russia. This, once again, emphasizes a distinct nature of supportive cooperation that should be subject to more detailed analysis in the future.

\subsection{Policy implications}

Our findings also can inform policies by highlighting risks and opportunities of future developments of nuclear energy. Our view of potential future expansion of nuclear power diverges from on the one hand 'techno-nationalists' who describe the development of nuclear power as primarily a national project (Hansen et al. 2015; Oreskes 2015) and on the other hand from energy modelers investigating whether nuclear power is needed to achieve climate targets (Clarke et al., 2014; Kim et al., 2014; Lehtveer and Hedenus, 2015b; Riahi et al., 2012) on the global scale and in purely economic terms. In contrast, we believe that cooperation between individual nations motivated by both economic and political (first and foremost energy security) considerations will play a central role in future nuclear power scenarios. This article is the first systematic analysis of 
the international technological nuclear landscape; this section reflects on the policy implications of this analysis.

It is important to recognize that international nuclear technological cooperation is likely to be dominated by a few major suppliers, most notably by Russia. Effective and safe models of such cooperation need to be developed for any scenario of significant nuclear power expansion to succeed. Currently there are two main models of nuclear reactor supply. The UAE has contracted a South Korean firm to build the country's first nuclear power plant and the Emiratis are paying for the plant. In contrast, Belarus and Turkey have signed build-own-operate contracts with Russia in which Russia pays, builds and owns the plants in exchange for a guaranteed electricity price for a certain number of years. If successful, it could help many newcomers to overcome the key challenge of achieving sufficient investment and domestic capacity to manage nuclear power. At the same time, there are still a number of uncertainties including how liability, investment recovery, and the risk of policy changes (IAEA, 2014b). Secondly, this may put client countries in uncertainty related to economic and financial stability of the supplier (such as the recent fluctuations of the Russian ruble).

Whatever the chosen model, the concentration of potential nuclear suppliers may present energy security risks. This is especially important since a serious motivation for introducing nuclear power for many countries is precisely energy security (Fuhrmann, 2012; Gourley and Stulberg, 2013; Price, 1990; Sovacool and Valentine, 2012). Nuclear power expansion decreases energy security risks by reducing imported fossil fuels, increasing the diversity of electricity systems (NEA, 2010; Watson and Scott, 2009), shielding consumers from fluctuations in fossil fuel prices (IAEA, 2008) and alleviating scarcity concerns (Macfarlane and Miller, 2007; NEA, 2008). However, it has the potential to introduce new ones, most importantly technological dependence. The risk of Russia a sole supplier of nuclear fuel for certain nuclear plants in the EU has been flagged as a security risk 
(European Commission, 2014). Hungary, Slovakia, Bulgaria and the Czech Republic, along with a third of Finland's nuclear power fleet can only be fueled by a single Russian company which has led Westinghouse (a competing nuclear fuel supplier) to warn the EU of these plants' energy insecurity (Oliver, 2014). This discussion highlights an important difference between dependence risks associated with nuclear power and those associated with oil and gas: while oil and gas risks are primarily short-term shocks which can be dealt with by strategies such as excess storage and diversity of suppliers, nuclear power risks entail long-term dependencies which cannot be addressed so simply as they lock client countries into particular dependencies that cannot be easily addressed.

Our analysis shows that dependencies in case of nuclear power are not limited to nuclear fuel and not concentrated in Europe (as is the case with natural gas). We show that suppliers of nuclear technology, especially of reactors and nuclear power plants may be more concentrated than those of oil and gas. Russia is the supplier in $43 \%$ of nuclear technology agreements, whereas Saudi Arabia supplies only $19 \%$ of internationally traded crude oil and Russia $20 \%$ of natural gas. Six countries account for $90 \%$ of suppliers of nuclear technology, while about 18 countries supply about $90 \%$ of oil and gas. ${ }^{26}$

While the international community has already recognized the importance of the international cooperation in the development of nuclear power, thus far, the focus has primarily been limited to fuel banks such as the IAEA-backed one initially proposed by Mohammed El-Baradei (IAEA, 2006) and the US-backed Global Nuclear Energy Partnership (GNEP) which was established in 2006 by the second Bush administration to support the safe expansion of nuclear power around the world primarily through expanding fuel services in established nuclear countries (US

\footnotetext{
${ }^{26}$ Calculated from IEA data (2016).
} 
Department of Energy, 2006). Neither of these initiatives include infrastructural development services as a primary focus, though GNEP was transformed into the International Framework for Nuclear Energy Cooperation and its mission to include nuclear infrastructure development (IFNEC, 2016) and the IAEA also hosts Technical Meetings to support newcomer countries in developing their national positions on nuclear power. Our results highlight that any expansion of nuclear energy would go far beyond fuel dependencies. Furthermore, much of the literature on future energy security highlights how low-carbon policies decreases fossil energy imports (Cherp et al., 2016; Jewell et al., 2014; 2016; McCollum et al., 2014). However, insofar as they increase the use of nuclear power they may introduce new patterns of dependence.

\section{References}

Bastian, M., Heymann, S., Jacomy, M., 2009. Gephi: An Open Source Software for Exploring and Manipulating Networks, in: Presented at the Proceedings of the Third International ICSWM Conference, pp. 361-362.

Bodin, Örjan, and Christina Prell, eds. 2011. Social Networks and Natural Resource Management: Uncovering the Social Fabric of Environmental Governance. Cambridge, UK: Cambridge University Press.

Bointner, R., 2014. Innovation in the energy sector: Lessons learnt from R\&D expenditures and patents in selected IEA countries. Energy Policy 73, 733-747. doi:10.1016/j.enpol.2014.06.001

Borgatti, S.P., Everett, M.G., Freeman, L.C., 2002. UCINET for Windows: Software for social network analysis. Analytic Technologies, Harvard, MA.

Bradford, P., 2015. Praise the Lord and pass the ammunition: Nuclear power and climate progress in the 21 st century [WWW Document]. Bulletin of the Atomic Scientists. URL http://thebulletin.org/commentary/praise-lord-and-pass-ammunition-nuclear-power-andclimate-progress-21st-century (accessed 5.31.16).

Brutschin, E., Jewell, J., 2018. International political economy of nuclear energy, in: Goldthau, A., Keating, M.F., Kuzemko, C. (Eds.), Handbook of International Political Economy of Energy and Natural Resources. Chelentham, UK, pp. 322-341.

Cherp, A., Adenikinju, A., Goldthau, A., Hernandez, F., Hughes, L., Jansen, J.C., Jewell, J., Olshanskaya, M., Soares de Oliveira, R., Sovacool, B.K., Vakulenko, S., 2012. Chapter 5 - Energy and Security, in: Global Energy Assessment: Toward a More Sustainable Future, Global Energy 
Assessment. Cambridge University Press, Cambridge University Press, Cambridge, UK and New York, NY, USA and the International Institute for Applied Systems Analysis, Laxenburg, Austria, pp. 325-383.

Cherp, A., Jewell, J., Vinichenko, V., Bauer, N., De Cian, E., 2016. Global energy security under different climate policies, GDP growth rates and fossil resource availabilities. Climatic Change 136. doi:10.1007/s10584-013-0950-x

Cherp, A., Vinichenko, V., Jewell, J., Suzuki, M., Antal, M., 2017. Comparing electricity transitions. Energy Policy 101, 612-628. doi:10.1016/j.enpol.2016.10.044

Choi, S., Jun, E., Hwang, I., Starz, A., Mazour, T., Chang, S., Burkart, A.R., 2009. Fourteen lessons learned from the successful nuclear power program of the Republic of Korea. Energy Policy 37, 5494-5508. doi:10.1016/j.enpol.2009.08.025

Clarke, L., Jiang, K., Akimoto, K., Babiker, M., Blanford, G., Fisher-Vanden, K., Hourcade, J.-C., Krey, V., Kriegler, E., Löschel, A., McCollum, D., Paltsev, S., Rose, S., Shukla, P.R., Tavoni, M., van der Zwaan, B., van Vuuren, D.P., 2014. Assessing transformation pathways, in: Edenhofer, O., Pichs-Madruga, R., Sokona, Y., Farahani, E., Kadner, S., Seyboth, K., Adler, A., Baum, I., Brunner, S., Eickemeier, P., Kriemann, B., Savolainen, J., Schlömer, S., Stechow, von, C., Zwickel, T., Minx, J.C. (Eds.), Climate Change 2014: Mitigation of Climate Change. Contribution of Working Group III to the Fifth Assessment Report of the Intergovernmental Panel on Climate Change. Cambridge University Press, Cambridge, United Kingdom and New York, NY, USA, pp. 413-510.

Currarini, S., Marchiori, C. \& Tavoni, A., 2016 Network Economics and the Environment: Insights and Perspectives. Environmental and Resource Economics 65, Springer: London.

Dorussen, H., Gartzke, E. A. \& Westerwinter, O., 2016. Networked international politics: Complex interdependence and the diffusion of conflict and peace. J Peace Res 53, 283-291.

Ebinger, C., Massy, K., 2010. Security Implications of the Expansion of Nuclear Energy. South Asian Survey 17, 75-89. doi:10.1177/097152311001700107

European Commission, 2014. Communication from the Commission to the European Parliament and the Council European Energy Security Strategy (No. COM(2014) 330). European Commission, Brussels.

Freeman, L.C., 1978. Centrality in social networks conceptual clarification. Social networks 1,215239. doi:10.1016/0378-8733(78)90021-7

Fuhrmann, M., 2012. Splitting Atoms: Why Do Countries Build Nuclear Power Plants? International Interactions 38, 29-57. doi:10.1080/03050629.2012.640209

Fuhrmann, M., 2009a. Spreading temptation: Proliferation and peaceful nuclear cooperation agreements. International Security 34, 7-41. 
Fuhrmann, M., 2009b. Taking a Walk on the Supply Side: The Determinants of Civilian Nuclear Cooperation. Journal of Conflict Resolution 53, 181-208. doi:10.1177/0022002708330288

Galluci, N., Schellenberger, M., 2017. Will the West Let Russia Dominate the Nuclear Market? Foreign Affairs.

Gallop, M. B., 2016. Endogenous networks and international cooperation. J Peace Res 53, 310-324.

Gourley, B., Stulberg, A.N., 2013. Correlates of nuclear energy, in: Stulberg, A.N., Fuhrmann, M. (Eds.), The Nuclear Renaissance and International Security. Stanford University Press, pp. 19-48.

Hafner-Burton, E.M., Kahler, M., Montgomery, A.H., 2009. Network Analysis for International Relations. International Organization 63, 559-592. doi:10.2307/40345947? ref $=$ no-xroute:d7e995bd5c49f3a29fa3e8d1e42efb03

Hansen, J., Emanuel, K., Caldeira, K., Wigley, T., 2015. Nuclear power paves the only viable path forward on climate change. The Guardian.

Hecht, G., 2001. Technology, Politics, and National Identity in France, in: Technologies of Power. Essays in Honor of Thomas Parke Hughes and Agatha Chipley Hughes. Cambridge, Massachusets and London, England, pp. 253-294.

Holloway, J. \& Koskinen, J., 2016. Multilevel Bilateralism and Multilateralism: States' Bilateral and Multilateral Fisheries Treaties and their Secretaries. in Multilevel Network. Analysis for the Social Sciences: Theory, Methods and Applications (eds. Lazega, E. \& Snijders, T. A.) 315-354. London: Springer International Publishing. doi:10.1007/978-3-319-24520-1

IAEA, 2015. Milestones in the development of a national infrastructure for nuclear power (No. No. NG-G-3.1 (Rev. 1)). IAEA, Vienna.

IAEA, 2014a. International Status and Prospects for Nuclear Power 2014 (No. GOV/INF/2014/13-GC(58)/INF/6). International Atomic Energy Agency.

IAEA, 2014b. Alternative contracting and ownership approaches for new nuclear power plants (No. IAEA-TECDOC-1750). International Atomic Energy Agency, Vienna.

IAEA, 2012. Nuclear Fuel Cycle Facilities (NFCIS). IAEA.

IAEA, 2010. Power Reactor Information System. Number of reactors under construction worldwide.

IAEA, 2008. Financing of new nuclear power plants. Vienna.

IAEA, 2006. IAEA Seeks Guarantees of Nuclear Fuel [WWW Document]. iaea.org. URL https://www.iaea.org/PrinterFriendly/NewsCenter/PressReleases/2006/prn200615.html (accessed 6.27.16). 
IFNEC, 2016. IFNEC - Organization [WWW Document]. ifnec.org. URL https://www.ifnec.org/ifnec/jcms/g_5189/organization (accessed 6.27.16).

International Energy Agency, 2016. Extended world energy balances, IEA World Energy Statistics and Balances. doi:http://dx.doi.org/10.1787/data-00513-en

Jacomy, M., Venturini, T., Heymann, S., Bastian, M., 2014. ForceAtlas2, a Continuous Graph Layout Algorithm for Handy Network Visualization Designed for the Gephi Software. PLoS ONE 9, e98679-12. doi:10.1371/journal.pone.0098679

Jewell, J., 2011. Ready for nuclear energy? An assessment of capacities and motivations for launching new national nuclear power programs. Energy Policy 39, 1041-1055. doi:10.1016/j.enpol.2010.10.041

Jewell, J., Ates, S.A., 2015. Introducing nuclear power in Turkey: A historic state strategy and future prospects. Energy Research \& Social Science 10, 273-282. doi:10.1016/j.erss.2015.07.011

Jewell, J., Cherp, A., Riahi, K., 2014. Energy security under de-carbonization scenarios: An assessment framework and evaluation under different technology and policy choices. Energy Policy 65, 743-760. doi:10.1016/j.enpol.2013.10.051

Jewell, J., Vinichenko, V., McCollum, D., Bauer, N., Riahi, K., Aboumahboub, T., Fricko, O., Harmsen, M., Kober, T., Krey, V., Marangoni, G., Tavoni, M., van Vuuren, D.P., van der Zwaan, B., Cherp, A., 2016. Comparison and interactions between the long-term pursuit of energy independence and climate policies. Nat. Energy 1, 16073-9. doi:10.1038/nenergy.2016.73

Keeley, J.F., 2009a. A List of Bilateral Civilian Nuclear Co-operation Agreements: Volume 1.

Keeley, J.F., 2009b. A List of Bilateral Civilian Nuclear Co-operation Agreements: Volume 5.

Kim, S.H., Wada, K., Kurosawa, A., Roberts, M., 2014. Nuclear energy response in the EMF27 study. Climatic Change 123, 443-460. doi:10.1007/s10584-014-1098-z

Kinne, B. J., 2013. Network dynamics and the evolution of international cooperation. American Political Science Review 107, 766-785.

Koomey, J., Hultman, N. E., \& Grubler, A., 2016. A reply to "Historical construction costs of global nuclear power reactors.” Energy Policy, 1-4. http://doi.org/10.1016/j.enpol.2016.03.052

Kroenig, M., 2009a. Exporting the Bomb: Why States Provide Sensitive Nuclear Assistance. Am. Pol. Sci. Rev. 103, 113-21. doi:10.1017/S0003055409090017

Kroenig, M., 2009b. Importing the Bomb. Journal of Conflict Resolution 53, 161.

Grubler, A., 2010. The costs of the French nuclear scale-up: A case of negative learning by doing. Energy Policy, 38(9), 5174-5188. http://doi.org/10.1016/j.enpol.2010.05.003 
Lantis, J.S., 2014. Economic Competition and Nuclear Cooperation. The Nonproliferation Review 21, 21-41. doi:10.1080/10736700.2014.880277

Lehtveer, M., Hedenus, F., 2015a. Nuclear power as a climate mitigation strategy - technology and proliferation risk. Journal of Risk Research 18, 1-18. doi:10.1080/13669877.2014.889194

Lehtveer, M., Hedenus, F., 2015b. How much can nuclear power reduce climate mitigation cost? - Critical parameters and sensitivity. ESR 6, 12-19. doi:10.1016/j.esr.2014.11.003

Lloyd, P., Mahutga, M.C., De Leeuw, J., 2009. Looking Back and Forging Ahead: Thirty Years of Social Network Research on the World-System. Journal of World-Systems Research 15, 48-85. doi:10.5195/jwsr.2009.335

Lovering, J. R., Yip, A., \& Nordhaus, T. (2016). Historical construction costs of global nuclear power reactors. Energy Policy, 91(C), 371-382. http://doi.org/10.1016/j.enpol.2016.01.011

Macfarlane, A.M., Miller, M., 2007. Nuclear Energy and Uranium Resources. Elements 3, 185192. doi:10.2113/gselements.3.3.185

Maoz, Z., 2012. How Network Analysis Can Inform the Study of International Relations. Conflict Man. \& Peace Sc. 29, 247-256. doi:10.1177/0738894212443341

Maoz, Z., 2011. Networks of Nations. Cambridge University Press, Cambridge. doi:10.1017/CBO9780511762659

McCollum, D., Bauer, N., Calvin, K., Kitous, A., Riahi, K., 2014. Fossil resource and energy security dynamics in conventional and carbon-constrained worlds. Climatic Change 123, 413-426. doi:10.1007/s10584-013-0939-5

Mez, L., Piening, A., 2002. Phasing-out nuclear power generation in Germany: policies, actors, issues and non-issues. Energy \& Environment 13, 161-181. doi:10.1260/0958305021501155

NEA, Nuclear Energy Agency, 2010. The security of energy supply and the contribution of nuclear energy. OECD.

NEA, Nuclear Energy Agency, 2008. NUCLEAR ENERGY OUTLOOK 2008 1-461.

Nordlund, C., 2011. International Networks, in: Barnett, G.A. (Ed.), Encyclopedia of Social Networks. pp. 425-431.

NSSPI (Center for Nuclear Security Science \& Policy Initiatives). n.d. News articles by country. URL: http://nsspi.tamu.edu/articlesbycountry. accessed 5.31.14.

Oliver, C., 2014. Westinghouse urges EU to break dependency on Russian nuclear fuel. Financial Times 1-2. 
ORA-LITE [Computer Software]. (2018). Center for Computational Analysis of Social and Organizational Systems, Institute for Software Research, Carnegie Mellon University. Retrieved from: http://www.casos.cs.cmu.edu/projects/ora/download.php.

Oreskes, N., 2015. There is a new form of climate denialism to look out for - so don't celebrate yet. The Guardian.

Poneman, D., 1982. Nuclear power in the developing world. George Allen \& Unwin, London.

Price, T., 1990. Political electricity. Oxford University Press, Oxford and New York.

Ramberg, B., 2015. Nuclear Power to the People. Foreign Affairs.

Riahi, K., Dententener, F., Gielen, D., Grubler, A., Jewell, J., Klimot, Z., Krey, V., McCollum, D., Nakicenovic, N., Pachauri, S., Rao, S., van Ruijven, B., van Vuuren, D.P., Wilson, C., 2012. Chapter 17 - Energy Pathways for Sustainable Development, in: Global Energy Assessment: Toward a More Sustainable Future, Global Energy Assessment. Cambridge University Press, Cambridge, UK and NY USA and the International Institute for Applied Systems Analysis, pp. 1203-1306.

Rogner, H.-H., 2013. World outlook for nuclear power. Energy Strategy Reviews 1, 291-295. doi:10.1016/j.esr.2012.12.001

ROSATOM, 2016. Rosatom international relations [WWW Document]. rosatom.ru. URL http://www.rosatom.ru/en/global-presence/international-relations/ (accessed 6.29.16).

Saban, D., Bonomo, F. \& Stier-Moses, N. E., 2010. Analysis and models of bilateral investment treaties using a social networks approach. Phys A Stat Mech its Appl 389, 3661-3673.

Saha, S., 2017. Russia’s nuclear diplomacy. Foreign Affairs.

Schneider, M., Froggatt, A., 2013. The World Nuclear Industry Status Report 2013. Paris, London, Mycle Schneider Consulting.

Serrano, M. Á. \& Boguñá, M., 2003. Topology of the world trade web. Phys Rev E - Stat Physics, Plasmas, Fluids, Relat Interdiscip Top 68, 4.

Smith, K.R., Rose, D.J., 1989. Nuclear Power, in: Electricity in Economic Development: the Experience of Northeast Asia. Greenwood Press, New York, pp. 145-185.

Sovacool, B.K., Valentine, S.V., 2012. The national politics of nuclear power: economics, security, and governance. Routledge, London and New York.

UN Comtrade, 2016. United Nations Commodity Trade Statistics Database. https://comtrade.un.org/db/mr/rfCommoditiesList.aspx?px $=$ H1\&cc $=2844$ 
US Department of Energy, 2006. The Global Nuclear Energy Partnership. US Government.

Warburg, G.F., 2012. Lessons Learned from the US-India Nuclear Cooperation Agreement. The Nonproliferation Review 19, 451-471. doi:10.1080/10736700.2012.734191

Wasserman, S., Faust, K., 1994. Social network analysis. Cambridge University Press, Cambridge, UK.

Watson, J., Scott, A., 2009. New nuclear power in the UK: A strategy for energy security? Energy Policy 37, 5094-5104. doi:10.1016/j.enpol.2009.07.019

Watts, D.J., Strogatz, S.H., 1998. Collective dynamics of "small-world" networks. Nature 393, 440-442. doi:10.1038/30918

WNA, n.d. Country Profiles. URL: http://www.world-nuclear.org/info/Country-Profiles/. (accessed 6.1.14).

WNA, 2016a. The World Nuclear Supply Chain. World Nuclear Association.

WNA, 2016b. Nuclear power in China [WWW Document]. World Nuclear Association. URL http://www.world-nuclear.org/information-library/country-profiles/countries-a-f/chinanuclear-power.aspx (accessed 6.24.16b).

WNA, 2016c. Nuclear Power in India [WWW Document]. World Nuclear Association. URL (accessed 8.31.16c).

WNN, 2016. Rosatom explains benefits of state backing to plant projects [WWW Document]. World Nuclear Association. URL http://www.world-nuclear-news.org/C-Rosatom-explainsbenefits-of-state-backing-to-plant-projects-11021601.html (accessed 6.29.16).

WNN, n.d. World Nuclear News Database. URL: http://www.world-nuclear-news.org. (accessed 5.15.14).

Wübbeke, J., Ting, G., 2016. China's Nuclear Industry Goes Global [WWW Document]. The Diplomat. URL http://thediplomat.com/2016/02/chinas-nuclear-industry-goes-global/ (accessed 6.24.16).

Zeng, M., Wang, S., Duan, J., Sun, J., Zhong, P., Zhang, Y., 2016. Review of nuclear power development in China_Environment analysis, historical stages, development status, problems and countermeasures. Renewable and Sustainable Energy Reviews 59, 1369-1383. doi:10.1016/j.rser.2016.01.045 


\section{Acknowledgements}

The research reported in this paper was supported by Central European University's Intellectual Theme Initiative, Central European University Foundation, Budapest (CEUBPF), the European Union's Horizon 2020 Research and Innovation Programme CD-LINKS under Grant agreement no. 642147 and the Leonardo da Vinci European Programme. The authors would like to thank participants of Central European University's departmental seminar, attendants of the PLATENSO conference for their input, A. Cherp, B. Vedres, C. Nordlund, as well as three anonymous reviewers for providing useful comments on a draft of this paper. The theses in this paper represent the work of the authors, but not the opinion of CEUBPF, H2020 or IIASA. 